\title{
Curcumin inhibits leptin gene expression and secretion in breast cancer cells by estrogen receptors
}

Kazem Nejati-Koshki ${ }^{*}$, Abolfazl Akbarzadeh ${ }^{2 *}$ and Mohammad Pourhassan-Moghaddam ${ }^{1,3}$

\begin{abstract}
Background: Recent studies suggested that leptin as a mitogenic factor might play an important role in the process of initiation and progression of human cancer. Therefore, it could be considered as a target for breast cancer therapy. A previous study has showed that expression of leptin gene could be modulated by activation of estrogen receptors. Curcumin is a diferuloylmethane that has been shown to interfere with multiple cell signaling pathways and extensive research over the last 50 years has indicated this polyphenol can both prevent and treat cancer. Based on the fact that targeting of leptin could be considered as a novel strategy for breast cancer therapy, the aim of this study is the investigation of potentiality of curcumin for inhibition of leptin gene expression and secretion, and also, its link with expression of estrogen receptors.
\end{abstract}

Methods: Cytotoxic effect of curcumin on T47D breast cancer cells was investigated by MTT assay test after 24 and 48 treatments. Thereafter, the cells treated with different concentrations of curcumin. The levels of leptin, estrogen receptor $a$ and estrogen receptor $\beta$ genes expression was measured in the treated and control cells by Reverse-transcription real-time PCR. Amount of secreted leptin in the culture medium was also determined by ELISA in both treated and untreated cells. Finally data were statistically analyzed by one-way ANOVA test.

Results: Analysis of MTT assay data showed that curcumin inhibits growth of T47D cells with dose dependent manner. There were also significant difference between control and treated cells in the levels of leptin, estrogen receptor a expression levels and the quantity of secreted leptin that both were decreased in the treated cells compared with control cells.

Conclusion: Based on the results, curcumin inhibits the expression and secretion of leptin and it could probably be used as a drug candidate for the breast cancer therapy through the leptin targeting in the future.

Keywords: Leptin, Curcumin, Breast cancer, T47D cell line

\section{Introduction}

Breast cancer is one of most commonly diagnosed types of cancer among women in 2012 and expected to account for $29 \%(226,870)$ of all new cancer cases among women [1]. Many factors are involved in the breast carcinogenesis, including adipocytokines like leptin [2].

\footnotetext{
* Correspondence: Nejatik@tbzmed.ac.ir; Akbarzadehab@tbzmed.ac.ir 'Department of Medical Biotechnology, Faculty of Advanced Medical Sciences, Tabriz University of Medical Sciences, Tabriz, Iran ${ }^{2}$ Department of Medical Nanotechnology, Faculty of Advanced Medical Sciences, Tabriz University of Medical Sciences, Tabriz, Iran Full list of author information is available at the end of the article
}

Leptin, a 167 amino acids hormone with a molecular mass of $16 \mathrm{kDa}$, is mainly secreted from adipose tissue [3]. It has central roles in the control of satiety, energy expenditure, food intake, many reproductive processes [4], affecting the metabolic and hematopoietic systems [5]. Beside the synthesis by adipose tissue as the main source [6], there have been identified other sources of leptin in the body including testicles [7], ovaries [6], placenta [8], cartilage and bone cells [9], skeletal muscle [10] and stomach [11]. Furthermore, the mitogenic, transforming or migration-induced properties of leptin have been revealed 
in many different cell types such as smooth muscle cells [12], normal and neoplastic colon cells [13,14]; and also normal and malignant mammary epithelial cells $[15,16]$. It has been shown that leptin induces growth and transformation in T47D breast cancer cells unlike normal breast epithelial cells [17]. Leptin acts through binding to its receptor known leptin receptor (ObR) located in the target cell membrane [18]. Significantly higher levels of both leptin and ObR expression have been found in cancer tissue relative to non-cancer epithelium [19]. Also, numerous breast cancer cell lines such as MCF-7 and T47D could express leptin and ObR [16]. All these observations confirm that leptin can act not only by endocrine and (or) paracrine action on mammary tumor cells, but also via an autocrine pathway. Additionally, a significant positive correlation has been obtained between leptin and ObR expressions with breast cancer tissue [20]. Therefore, this paracrine-autocrine leptin axis could become a target for leptin-inhibiting drugs in cancer treatment and prevention.

Results of a study showed that the ratio of ER $\alpha$ to $\mathrm{ER} \beta$, in human adipose tissue, was significantly correlated with the level of serum leptin in vivo [21]. Thus, $\mathrm{ER} \alpha$ and $\mathrm{ER} \beta$ maybe have different roles in the regulation of leptin expression.

Curcumin (diferuloylmethane), a derivative of turmeric is one of the most commonly used and highly researched phytochemicals. It exhibits promising pharmacological activities and has demonstrated beneficial effects in terms of cancer cell proliferation, growth, survival, apoptosis, migration, invasion, angiogenesis, and metastasis [22]. Considering important roles of leptin in the breast cancer biology, in this study we investigated the possible variations in the leptin secretion and expression as well as expression of ERs in the T47D breast cancer cell line after its treatment with pure curcumin.

\section{Methods}

Our study has been conducted on cell lines and it is compatible with Helsinki ethical codes, and it has been approved by ethics committee of our institute.

\section{Chemicals and reagents}

Curcumin (Sigma, Germany), MTT (Sigma, Germany), Leptin ELISA kit (Labor diagnostika nord gmbh \& co. kg, Germany), Fetal bovine serum (Gibco, USA), Phenol-red free RPMI 1640 with L-glutamine (Gibco, USA), T47D cells (Pasteur Institute of Iran), Sodium bicarbonate (Merck, Germany), Penicillin (SERVA, Germany), Streptomycin (Merck, Germany), Amphotericin B (Merck, Germany), TRIZOL Reagent (Invitrogen, USA), FirstStrand Synthesis kit (Fermentas, USA), Syber Green-I reagent (Fermentas, USA).

\section{Cell culture}

T47D cells were cultured in RPMI1640 (with glutamine) supplemented with $10 \%$ FBS, penicillin, streptomycin and amphotericin $\mathrm{B}$ and incubated at $37^{\circ} \mathrm{C}$ in a humidified atmosphere containing 5\% Co2.

\section{MTT assay and cell treatment}

The cytotoxic effect of curcumin on T47D cells was studied by 24 and 48 MTT assays. Briefly, 2500 cell/well were cultivated in a 96 well culture plate. After $24 \mathrm{~h}$ incubation in $37^{\circ} \mathrm{C}$ cells were treated with different concentrations of curcumin ( 0 to $100 \mu \mathrm{M})$ for 24 and $48 \mathrm{~h}$ in the quadruplicate manner. Then, medium of all wells were removed carefully and $50 \mu \mathrm{l} 2 \mathrm{mg} / \mathrm{ml} \mathrm{MTT}$ was added to each well and incubated for $4.5 \mathrm{~h}$, followed by addition of $200 \mu \mathrm{l}$ DMSO. Thereafter, Sorensens' glycine buffer was added and absorbance of each well was read at $570 \mathrm{~nm}$. For data analysis, mean OD of each well was calculated. Then, percent of cells viability was calculated according to this formula: percent of cells viability $=$ mean $\mathrm{OD}$ of test wells/mean OD of control wells $\times 100$. Finally, a graph was plotted using SPSS 16.0 and IC50 of curcumin on T47D was determined on graph [23].

For studying the inhibitory effect of curcumin on leptin, ER $\alpha$ and ER $\beta$ expression as well as leptin secretion, $1 \times 10^{5}$ cells/wells were treated in a 6 -well plate with different concentrations of curcumin $(0,10,20$, 30 and $40 \mu \mathrm{M}$ ) for 24-48 h. A control group containing $0.1 \%$ DMSO without curcumin served as vehicle control.

\section{Isolation of total RNA and CDNA synthesis}

Total RNA was extracted from attached cells using TRIZOL Reagent according to the manufacturer's instructions. The concentration of prepared RNA was measured using a NanoDrop spectrophotometer (Termoscientific, USA) and its integrity was confirmed by electrophoresis on $1.5 \%$ agarose gel containing $1 \%$ formaldehyde. After RNA preparation, cDNA was synthesized using the FirstStrand Synthesis kit according to the manufacturer's instructions. The synthesized cDNA was immediately used in a real-time PCR or stored at $-70^{\circ} \mathrm{C}$ for later use.

\section{Real-time PCR}

The real-time PCR was used for measurement of leptin, $E R \alpha$, and ER $\beta$ expression levels in the control and treated cells. $\beta$-actin gene expression was used as the internal control. The real-time PCR reaction was done using the Syber Green-I reagent in the Rotor Gene 6000 system (Corbett research, Australia) according to the manufacturer's instructions in a triplicate manner. The amplification conditions were as follows: leptin (2 min at $95^{\circ} \mathrm{C}$ and a two-step cycle of $95^{\circ} \mathrm{C}$ for $15 \mathrm{~s}$ 
Table 1 Primers used for real-time PCR amplifications

\begin{tabular}{llll}
\hline Primer & $\begin{array}{l}\text { Primer } \\
\text { length }\end{array}$ & Sequence (5' to $\mathbf{3}^{\prime}$ ) & $\begin{array}{l}\text { Product } \\
\text { size (bp) }\end{array}$ \\
\hline Leptin forward & 22 & CACCAAAACCCTCATCAAGACA & 80 \\
Leptin reverse & 24 & CTITCTGTTGGAGGAGACTGACT & \\
ERa forward & 20 & GCCAGCAGGTGCCCTACTAC & 132 \\
ERa reverse & 23 & TGGTACTGGCCAATCTTTCTCTG & \\
ERß forward & 19 & AAGAGCTGCCAGGCCTGCC & 268 \\
ERß reverse & 21 & GCGCACTGGGGCGGCTGATCA & \\
B-actin forward & 20 & TGGACTTCGAGCAAGAGATG & 137 \\
B-actin reverse & 20 & GAAGGAAGGCTGGAAGAGTG & \\
\hline
\end{tabular}

and $60^{\circ} \mathrm{C}$ for $40 \mathrm{~s}$ for 40 cycles), ER $\alpha\left(5 \mathrm{~min}\right.$ at $95^{\circ} \mathrm{C}$ and a two-step cycle of $95^{\circ} \mathrm{C}$ for $30 \mathrm{~s}$ and $57^{\circ} \mathrm{C}$ for $40 \mathrm{~s}$ for 40 cycles), and $\mathrm{ER} \beta$ ( $5 \mathrm{~min}$ at $95^{\circ} \mathrm{C}$ and a two-step cycle of $95^{\circ} \mathrm{C}$ for $15 \mathrm{~s}$ and $64^{\circ} \mathrm{C}$ for $40 \mathrm{~s}$ for 40 cycles). Sequences of used primers were shown in Table 1. Changes in leptin, ER $\alpha$, and ER $\beta$ expression levels between the control and treated T47D cells were calculated by the $2^{-\triangle \Delta C T}$ method.

\section{Measurement of the secreted leptin}

For analysis of possible effect of curcumin on amount of secreted leptin in the treated cells compared with the control cells, leptin concentration was measured in the supernatant media of cells using a human leptin ELISA kit according to the manufacturer's instructions.

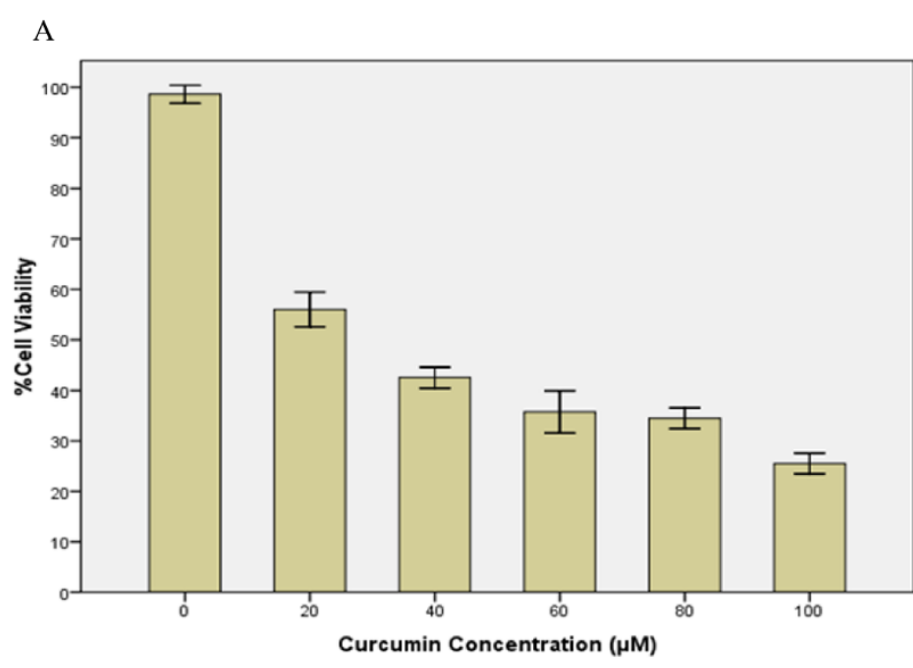

Error Bars: $95 \% \mathrm{Cl}$

B

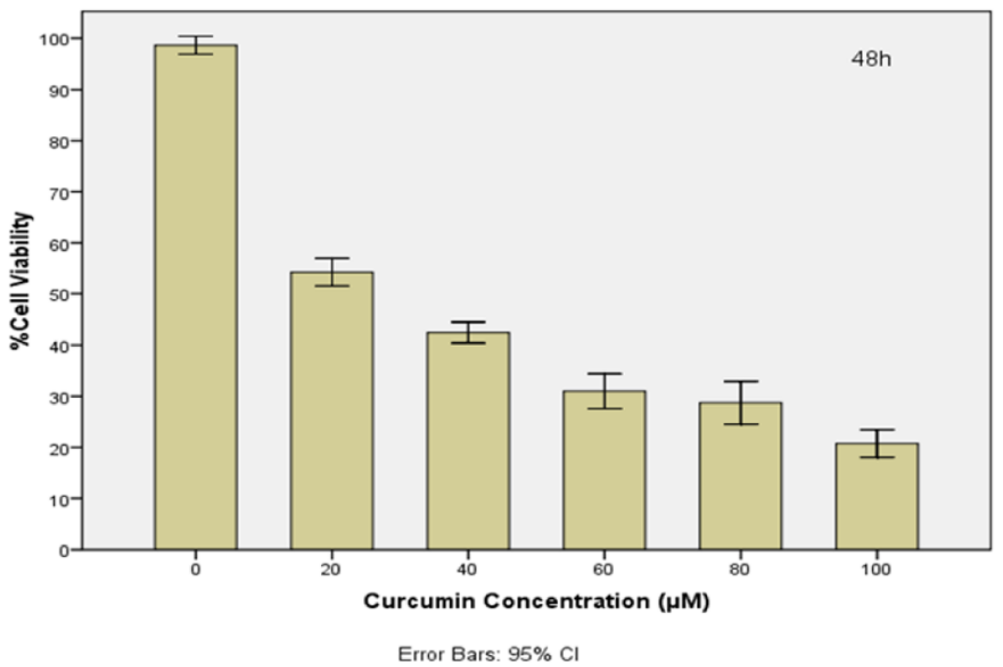

Figure 1 The cytotoxic effect of curcumin on T47D cells during $24 \mathrm{~h}$ (A) and $48 \mathrm{~h}$ MTT assays. 


\section{Statistical analysis}

Statistical analysis was performed with SPSS 18.0 software. Data are expressed as mean \pm standard deviation. All experiments were performed in triplicate. The differences in expression levels of leptin, ER $\alpha$ and $E R \beta$ as well as quantity of secreted leptin between the control and treated cells were analyzed by one-way ANOVA, followed by Dunett's multiple comparison tests. A p-value $<0.05$ was considered as significant.

\section{Results}

\section{MTT assay}

Data analysis of cytotoxicity assay showed that IC50 of curcumin on T47D breast cancer cell line was 28 and $24 \mu \mathrm{M}$ for 24 and $48 \mathrm{~h}$ MTT assays, respectively (Figure 1). The obtained IC50s were dose-dependent.

\section{Quantitative real- time PCR}

Real-time PCR results showed a significant decrease in leptin expression in the treated cells compared to the control cells ( $p$-value $<0.05$ ) (Figure 2$)$. We, also, measured the expression levels of $E R \alpha$, and $E R \beta$ in the treated and control cells. Although, no significant difference was detected in ER $\beta$ expression levels between the treated and the control cells, a significant decrease was observed in the ER $\alpha$ mRNA level (p-value $<0.05$ ) (Figure 3). Therefore, the ER $\alpha / E R \beta$ expression ratio has been decreased in the treated cells compared to the control cells. There was no significant difference between the DMSO control and the DMSO-free control (the $0 \mu \mathrm{M}$ concentration of curcumin).

Data analysis revealed a positive significant link between leptin gene expression and ER $\alpha$ gene expression level and no link between leptin and ER $\beta$ expression level in curcumin treated cells compared to the control cells. In addition, a positive significant correlation was found between mRNA level of leptin and ER $\alpha / E R \beta$ expression ratio.

\section{Measurement of secreted leptin}

Amounts of secreted leptin were evaluated using ELISA. A significant difference was found between the control and treated cells in term of secreted leptin (Figure 4). This finding was in accordance with inhibition of leptin gene expression by curcumin.

\section{Discussion}

This study demonstrates that curcumin, most active constituent of turmeric, can inhibit leptin gene expression and secretion in T47D breast cancer cells and this decrease in leptin gene expression and secretion was positively associated with decrease of ER $\alpha$ gene expression. These results indicate that curcumin has a strong potential to interact with the expression of leptin gene, which has significant roles in carcinogenesis and proliferation of breast cancer cells [2]. Regarding to the critical role of leptin in breast carcinogenesis [24], there are many attempts to inhibit leptin function and secretion. Gonzalez et al. inhibited growth of murine mammary cancer cell and xenograft tumor model of human breast cancer cell lines by leptin peptide antagonist [25]. In addition, leptin analog mimicking its action [26] and anti-leptin receptor monoclonal antibody [27] are also another approaches for interfering with the leptin function. In the other studies, administrations of some compounds including b3-adrenoreceptor agonist, conjugated linoleic Acid, isoflavone, resveratrol and bitter melon lead to decreased secretion and lower levels of serum leptin [28]. The current work, however, aimed to direct inhibition of leptin expression and secretion in human

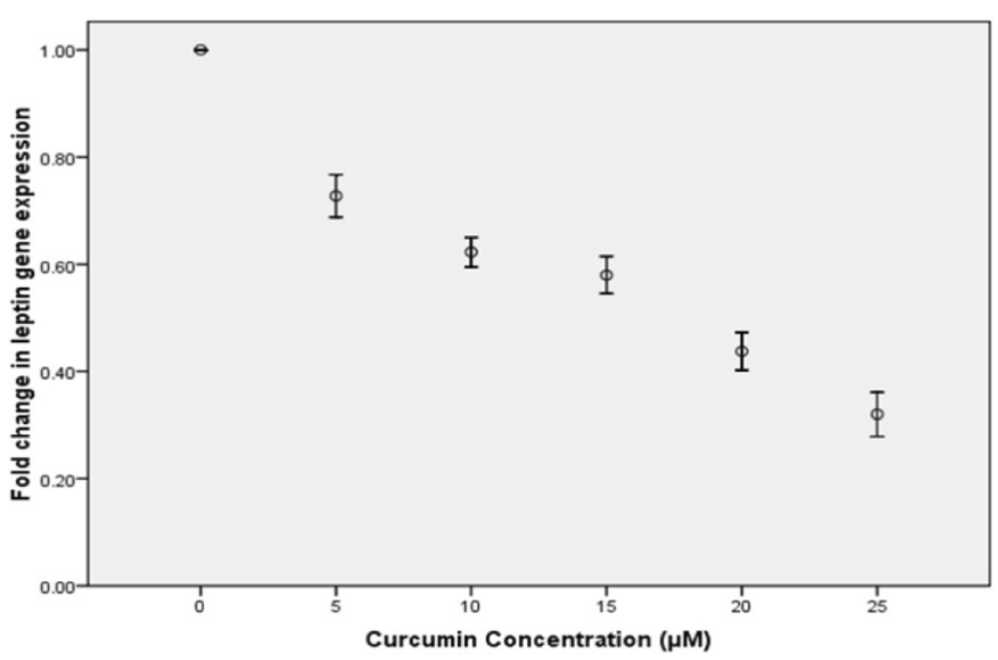

Figure 2 Effect of curcumin on leptin expression levels in T47D cells. 


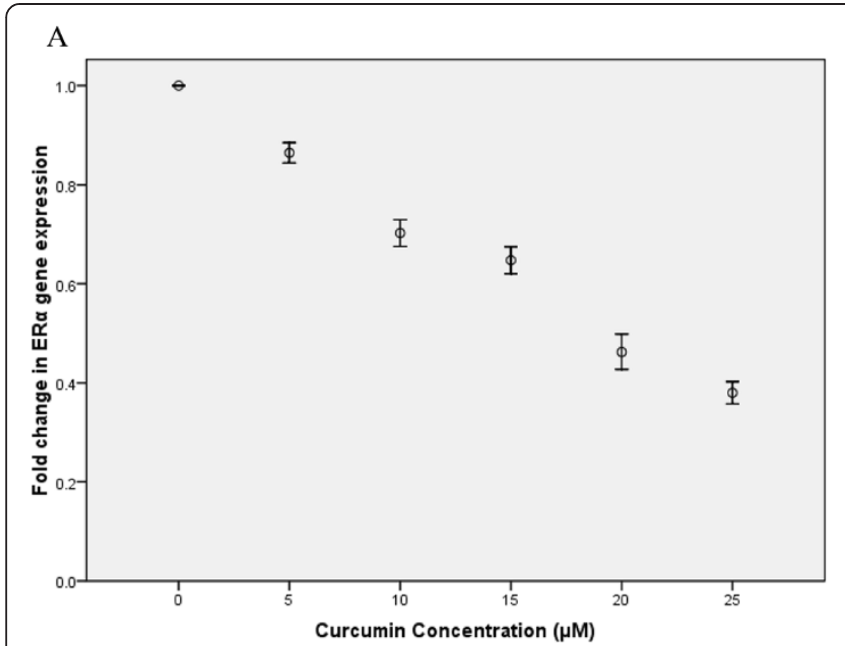

B

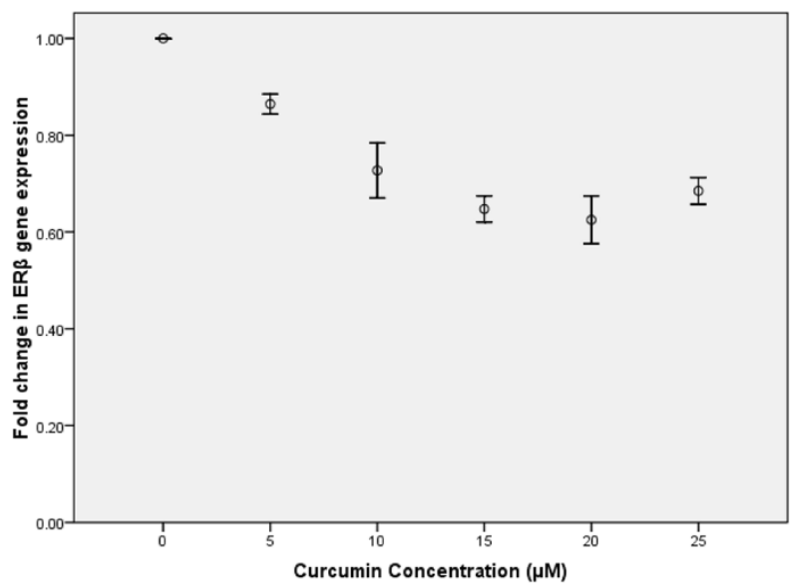

Figure 3 Effect of curcumin on expression levels of ERa (A) and ER $\beta$ (B) genes in the T47D cells. As the figure shows, there is a significant decrease in ERa gene expression levels with increasing in the curcumin concentration ( $p$-value $<0.05$ ), unlike ER $\beta$ gene expression levels.

T47D breast cancer cell line using curcumin. Due to significant anti-cancer effects of curcumin on various types of cancers such as gastrointestinal, genitourinary, gynecological, hematological, pulmonary, thymic, brain, breast, and bone [29], it can be used as a chemotherapeutic agent for breast cancer therapy.

The mechanisms by which curcumin exerts its anticancer effects are comprehensive and diverse, targeting many levels of regulation in the processes of cellular growth and apoptosis. Curcumin has an inhibitory effect on both NF-kB and AP-1 activation. curcumin has been shown to suppress the expression of a variety of NF- $\mathrm{KB}$ regulated gene products involved in carcinogenesis and tumor growth including cyclin D1, VEGF, COX-2, c-myc, Bcl-2, ICAM-1 and MMP-9 [30]. In addition, Curcumin has been shown to suppress the expression of cyclin D1 in many types of cancer including head and neck, colon, bladder, breast, cervical and pancreatic carcinomas [31]. Our results, regarding inhibition of leptin expression, confirm these findings, also demonstrating another role for curcumin effect that probably acts through estrogen receptors. It has been demonstrated that expression of leptin has positive correlation with expression of ER $\alpha$ and negative correlation with ER $\beta$ expression [32]. In addition, leptin promoter has response elements for both ER $\alpha$ and ER $\beta$ [33]; where, probably competition between ER $\alpha$ and ER $\beta$ in attachment to this place causes reduction of leptin gene transcription by

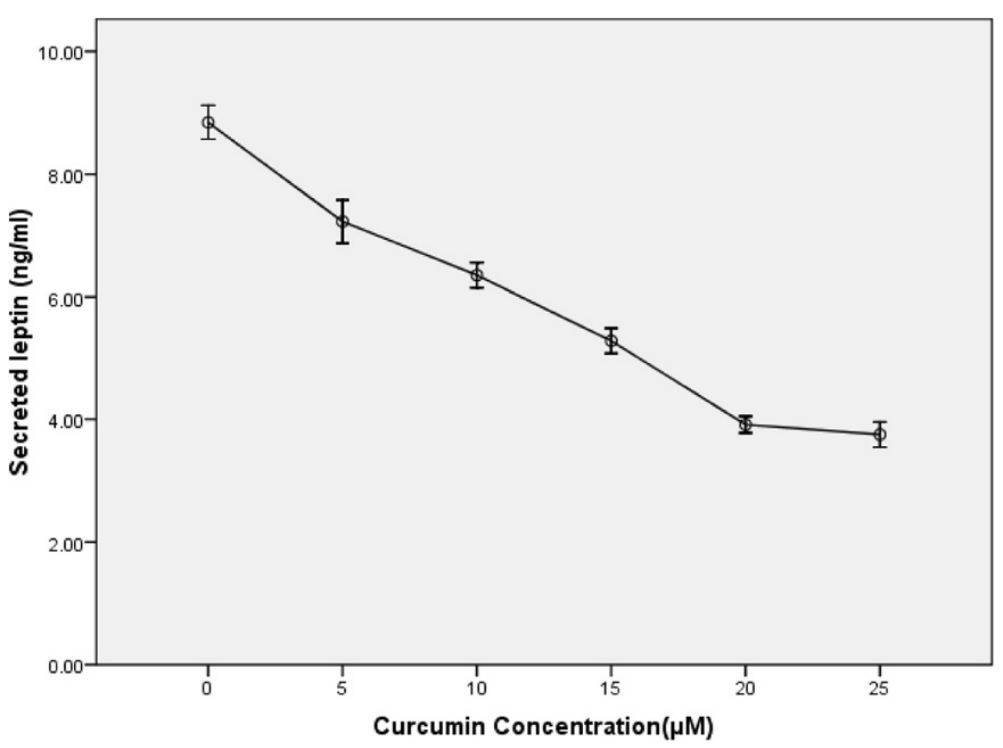

Figure 4 Effect of curcumin on leptin secretion in T47D cells. 
lowered activity of the leptin promoter. Nejati-Koshki and et al. reported that silibinin can decrease leptin gene expression and secretion in T47D cells thought activation of ER $\beta$ gene expression [34]. In the current study, we showed that reduction of leptin expression by curcumin positively correlates with expression of ER $\alpha$. Therefore, it seems that one of the possible mechanisms of curcumin inhibitory effect on leptin expression could be through ERs. However, many studies need to determine the exact molecular mechanism (s) involved in the reduction of leptin gene expression and secretion by curcumin [35-54].

\section{Conclusion}

In summary, we demonstrated that curcumin could inhibit expression and secretion of leptin in T47D breast cancer cells. Regarding to the significant roles of leptin in breast carcinogenesis, its inhibition could be considered as a novel strategy for treatment of breast cancer in the future.

\section{Competing interests}

The authors declare that they have no competing interests.

\section{Authors' contributions}

SWJ conceived the study and participated in its design and coordination. AA participated in the sequence alignment and drafted the manuscript. YH, and KNK helped in drafting the manuscript. All authors read and approved the final manuscript.

\section{Acknowledgments}

The authors would like to thanks Faculty of advanced medical sciences for granting and technical assistance.

\section{Author details}

'Department of Medical Biotechnology, Faculty of Advanced Medical Sciences, Tabriz University of Medical Sciences, Tabriz, Iran. ${ }^{2}$ Department of Medical Nanotechnology, Faculty of Advanced Medical Sciences, Tabriz University of Medical Sciences, Tabriz, Iran. ${ }^{3}$ Department of Clinical Biochemistry, Faculty of Medicine, Tabriz University of Medical Sciences, Tabriz, Iran.

Received: 11 March 2014 Accepted: 28 April 2014

Published: 23 December 2014

\section{References}

1. Siegel R, Naishadham D, Jemal A: Cancer statistics, 2012. CA Cancer J Clin 2012, 62(1):10-29.

2. Vona-Davis L, Rose DP: Adipokines as endocrine, paracrine, and autocrine factors in breast cancer risk and progression. Endocr Relat Cancer 2007, 14(2):189-206

3. Zhang Y, Proenca R, Maffei M, Barone M, Leopold L, Friedman JM: Positional cloning of the mouse obese gene and its human homologue. Nature 1994, 372(6505):425-432.

4. Collins S, Kuhn CM, Petro AE, Swick AG, Chrunyk BA, Surwit RS: Role of leptin in fat regulation. Nature 1996, 380(6576):677.

5. Fantuzzi $G$, Faggioni $R$ : Leptin in the regulation of immunity, inflammation, and hematopoiesis. J Leukoc Biol 2000, 68(4):437-446.

6. Löffler S, Aust G, Köhler U, Spanel-Borowski K: Evidence of leptin expression in normal and polycystic human ovaries. Mol Hum Reprod 2001, 7(12):1143-1149.

7. Soyupek S, Armağan A, Serel TA, Hoşcan MB, Perk H, Karaöz E, Candir O: Leptin expression in the testicular tissue of fertile and infertile men. Arch Androl 2005, 51(3):239-246.
8. Masuzaki H, Ogawa Y, Sagawa N, Hosoda K, Matsumoto T, Mise H, Nishimura H, Yoshimasa Y, Tanaka I, Mori T, Nakao K: Nonadipose tissue production of leptin: leptin as a novel placenta-derived hormone in humans. Nat Med 1997, 3(9):1029-1033.

9. Morroni M, De Matteis R, Palumbo C, Ferretti M, Villa I, Rubinacci A, Cinti S, Marotti G: In vivo leptin expression in cartilage and bone cells of growing rats and adult humans. J Anat 2004, 205(4):291-296.

10. Solberg R, Aas V, Thoresen GH, Kase ET, Drevon CA, Rustan AC, Reseland JE: Leptin expression in human primary skeletal muscle cells is reduced during differentiation. J Cell Biochem 2005, 96(1):89-96.

11. Mix H, Widjaja A, Jandl O, Cornberg M, Kaul A, Göke M, Beil W, Kuske M, Brabant G, Manns MP, Wagner S: Expression of leptin and leptin receptor isoforms in the human stomach. Gut 2000, 47(4):481-486.

12. Oda A, Taniguchi T, Yokoyama M: Leptin stimulates rat aortic smooth muscle cell proliferation and migration. Kobe J Med Sci 2001, 47(3):141-150.

13. Hardwick JC, Van Den Brink GR, Offerhaus GJ, Van Deventer SJ, Peppelenbosch MP: Leptin is a growth factor for colonic epithelial cells. Gastroenterology 2001, 121(1):79-90

14. Liu Z, Uesaka T, Watanabe H, Kato N: High fat diet enhances colonic cell proliferation and carcinogenesis in rats by elevating serum leptin. Int J Oncol 2001, 19(5):1009-1014.

15. Dieudonne MN, Machinal-Quelin F, Serazin-Leroy V, Leneveu MC, Pecquery R, Giudicelli Y: Leptin mediates a proliferative response in human MCF7 breast cancer cells. Biochem Biophys Res Commun 2002, 293(1):622-628.

16. Laud K, Gourdou I, Pessemesse L, Peyrat JP, Djiane J: Identification of leptin receptors in human breast cancer: functional activity in the T47-D breast cancer cell line. Mol Cell Endocrinol 2002, 188(1-2):219-226.

17. Hu X, Juneja SC, Maihle NJ, Cleary MP: Leptin - a growth factor in normal and malignant breast cells and for normal mammary gland development. J Natl Cancer Inst 2002, 94(22):1704-1711.

18. Tartaglia LA: The leptin receptor. J Biol Chem 1997, 272(10):6093-6096.

19. Ishikawa M, Kitayama J, Nagawa H: Enhanced expression of leptin and leptin receptor (OB-R) in human breast cancer. Clin Cancer Res 2004 10(13):4325-4331.

20. Koda M, Sulkowska M, Kanczuga-Koda L, Jarzabek K, Sulkowski S: Expression of leptin and its receptor in female breast cancer in relation with selected apoptotic markers. Folia Histochem Cytobiol 2007, 45(Suppl 1):S187-S191.

21. Shin JH, Hur JY, Seo HS, Jeong YA, Lee JK, Oh MJ, Kim T, Saw HS, Kim SH: The ratio of estrogen receptor alpha to estrogen receptor beta in adipose tissue is associated with leptin production and obesity. Steroids 2007, 72(6-7):592-599.

22. Shehzad A, Wahid F, Lee YS: Curcumin in cancer chemoprevention: molecular targets, pharmacokinetics, bioavailability, and clinical trials. Arch Pharm (Weinheim) 2010, 343(9):489-499.

23. Pourhassan M, Zarghami N, Rahmati M, Alibakhshi A, Ranjbari R: The inhibitory effect of Curcuma longa extract on telomerase activity in A549 lung cancer cell line. Afr J Biotechnol 2010, 9(6):912-919.

24. Garofalo C, Surmacz E: Leptin and cancer. I Cell Physiol 2006, 207(1):12-22

25. Gonzalez RR, Watters A, Xu Y, Singh UP, Mann DR, Rueda BR, Penichet ML: Leptin-signaling inhibition results in efficient anti-tumor activity in estrogen receptor positive or negative breast cancer. Breast Cancer Res 2009, 11(3):R36.

26. Peters JH, Simasko SM, Ritter RC: Leptin analog antagonizes leptin effects on food intake and body weight but mimics leptin-induced vagal afferent activation. Endocrinology 2007, 148:2878-2885.

27. Fazeli M, Zarkesh-Esfahani H, Wu Z, Maamra M, Bidlingmaier M, Pockley AG Watson P, Matarese G, Strasburger CJ, Ross RJ: Identification of a monoclonal antibody against the leptin receptor that acts as an antagonist and blocks human monocyte and T cell activation. I Immunol Methods 2006, 312(1-2):190-200.

28. Ray A, Cleary MP: Leptin as a potential therapeutic target for breast cancer prevention and treatment. Expert Opin Ther Targets 2010, 14(4):443-451.

29. Shehzad A, Lee J, Lee YS: Curcumin in various cancers. Biofactors 2013, 1:56-68.

30. Kunnumakkara AB, Diagaradjane P, Anand P, Harikumar KB, Deorukhkar A, Gelovani J, Guha S, Krishnan S, Aggarwal BB: Curcumin sensitizes human colorectal cancer to capecitabine by modulation of cyclin D1, COX-2, MMP-9, VEGF and CXCR4 expression in an orthotopic mouse model. Int J Cancer 2009, 125:2187-2197. 
31. Singh RP, Sharma G, Dhanalakshmi S, Agarwal C, Agarwal R: Suppression of advanced human prostate tumor growth in athymic mice by silibinin feeding is associated with reduced cell proliferation, increased apoptosis, and inhibition of angiogenesis. Mol Cancer Ther 2009, 8(6):1606-1612.

32. Yi KW, Shin JH, Seo HS, Lee JK, Oh MJ, Kim T, Saw HS, Kim SH, Hur JY: Role of estrogen receptor-alpha and -beta in regulating leptin expression in 3 T3-L1 adipocytes. Obesity (Silver Spring) 2008, 16(11):2393-2399.

33. O'Neil JS, Burow ME, Green AE, McLachlan JA, Henson MC: Effects of estrogen on leptin gene promoter activation in MCF-7 breast cancer and JEG-3 choriocarcinoma cells: selective regulation via estrogen receptors alpha and beta. Mol Cell Endocrinol 2001, 176(1-2):67-75.

34. Nejati-Koshki K, Zarghami N, Pourhassan-Moghaddam M, Rahmati-Yamchi M, Mollazade M, Nasiri M, Esfahlan RJ, Barkhordari A, Tayefi-Nasrabadi H: Inhibition of leptin gene expression and secretion by silibinin: possible role of estrogen receptors. Cytotechnology 2012, 64(6):719-726.

35. Akbarzadeh A, Mikaeili H, Asgari D, Zarghami N, Mohammad R, Davaran S: Preparation and in-vitro evaluation of doxorubicin-loaded $\mathrm{Fe}_{3} \mathrm{O}_{4}$ magnetic nanoparticles modified with biocompatible copolymers. Int J Nanomedicine 2012, 7:511-526.

36. Akbarzadeh A, Zarghami N, Mikaeili H, Asgari D, Amir Mohammad G, Khaksar Khiabani H, Soodabeh D: Synthesis, characterization and in vitro evaluation of novel polymer-coated magnetic nanoparticles for controlled delivery of doxorubicin. Int J Nanotechnol Sci Environ 2012, 5:13-25.

37. Akbarzadeh A, Samiei M, Joo SW, Anzaby M, Hanifehpour Y, Nasrabadi HT, Davaran S: Synthesis, characterization and in vitro studies of doxorubicinloaded magnetic nanoparticles grafted to smart copolymers on A549 lung cancer cell line. J Nanobiotechnol 2012, 10:46-58.

38. Zohreh E, Nosratollah Z, Manoutchehr K, Soumaye A, Abolfazl A, Mohammad R, Zohreh Mohammad T, Kazem N-K: Inhibition of hTERT Gene Expression by Silibinin-Loaded PLGA-PEG-Fe3O4 in T47D Breast Cancer Cell Line. Biolmpacts 2013, 3(2):67-74.

39. Davaran S, Alimirzalu S, Nejati-Koshki K, Hamid Tayefi N, Abolfazl A, Amir Ahmad K, Mojtaba A, Somayeh A: Synthesis and study of physicochemical characteristics of $\mathrm{Fe} 3 \mathrm{O} 4$ magnetic nanocomposites based on poly (Nisopropylacrylamide) for anti-cancer drugs delivery. Asian Pac J Cancer Prev 2014, 15(1):049-054.

40. Rogaie R-S, Nosratollah Z, Abolfazl B, Akram E, Abolfazl A, Mustafa R-T: Studies of the relationship between structure and antioxidant activity in interesting systems, including tyrosol, hydroxytyrosol derivatives indicated by quantum chemical calculations. Soft 2013, 2:13-18.

41. Nejati-Koshki K, Akbarzadeh A, pourhasan-Moghadam M, woo joo S: Inhibition of leptin and leptin receptor gene expression by silibinincurcumin combination. Asian Pac J Cancer Prev 2013, 14(11):6595-6599.

42. Ghasemali S, Nejati-Koshki K, Akbarzadeh A, Tafsiri E, Zarghami N, RahmatiYamchi M, Alizadeh E, Barkhordari A, Tozihi M, Kordi S: Study of inhibitory effect of $\beta$-Cyclodextrin-HelenalinComplex on HTERT Gene Expression in T47D breast cancer cell line by Real TimeQuantitative PCR (q-PCR). Asian Pac J Cancer Prev 2013, 14(11):6949-6953.

43. Mollazade M, Nejati-Koshki K, Abolfazl A, Younes H, Zarghami N, Sang Woo J: PAMAM Dendrimers arugment inhibitory effect of curcumin on cancer cell proliferation: possible inhibition of telomerase. Asian Pac J Cancer Prev 2013, 14(11):6925-6928.

44. Davaran S, Rezaei A, Alimohammadi S, Amir Ahmad K, Kazem N-K, Hamid Tayefi N, Abolfazl A: Synthesis and Physicochemical Characterization of Biodegradable star-shaped poly lactide-co-glycolide- $\beta$-cyclodextrin copolymer Nanoparticles Containing Albumin. Adv Nanoparticles 2014, 3:14-22.

45. Davaran S, Abolfazl Akbarzadeh1, Kazem N-K, Somayeh A, Mahmoud Farajpour G, Mahsa Mahmoudi S, Akbar R, Amir Ahmad K: In vitro studies of NIPAAMMAA-VP copolymer-coated magnetic nanoparticles for controlled anticancer drug release. J Encapsulation Adsorption Sci 2013, 3:108-115.

46. Nasiri M, Zarghami N, Koshki KN, Mollazadeh M, Moghaddam MP, Yamchi MR, Esfahlan RJ, Barkhordari A, Alibakhshi A: Curcumin and silibinin inhibit telomerase expression in T47D human breast cancer cells. Asian Pac J Cancer Prev 2013, 14(6):3449-3453.

47. Abolfazl A, Samiei M, Soodabeh D: Magnetic nanoparticles: preparation, physical properties and applications in biomedicine. Nanoscale Res Lett 2012, 7:144-157

48. Alireza V, Haleh M, Mohammad S, Samad Mussa F, Nosratollah Z, Mohammad K, Abolfazl A, Soodabeh D: Quantum dots: synthesis, bioapplications, and toxicity. Nanoscale Res Lett 2012, 7:276.
49. Abolfazl A, Rogaie R-S, Soodabeh D, Sang Woo J, Nosratollah Z, Younes H, Mohammad S, Mohammad K, Kazem N-K: Liposome: classification, preparation, and applications. Nanoscale Res Lett 2013, 8:102.

50. Mohammad P-M, Mohammad R-Y, Abolfazl A, Hadis D, Kazem N-K, Younes $\mathrm{H}$, Sang Woo J: Protein detection through different platforms of immuno-loop-mediated isothermal amplification. Nanoscale Res Lett 2013, 8:485

51. Ebrahimnezhad Z, Zarghami N, Keyhani M, Amirsaadat S, Akbarzadeh A, Rahmati M, Mohammad Taheri Z, Nejati-Koshki K: Inhibition of hTERT Gene Expression by Silibinin-Loaded PLGA-PEG-Fe3O4 in T47D Breast Cancer Cell Line. Bioimpacts 2013, 3(2):67-74.

52. Pourhassan-Moghaddam M, Rahmati-Yamchi M, Akbarzadeh A, Daraee H, Nejati-Koshki K, Hanifehpour Y, Joo SW: Protein detection through different platforms of immuno-loop-mediated isothermal amplification. Nanoscale Res Lett. 2013, 8(1):485.

53. Esfahlan RJ, Zarghami N, Esfahlan AJ, Mollazadeh M, Nejati K, Nasiri M: Basic of DNA biosensors and cancer diagnosis. The Possible Impact of Obesity on Androgen, Progesterone and Estrogen Receptors (ERa and ER $\beta$ ) Gene Expression in Breast Cancer Patients. Breast Cancer (Auckl) 2011, 5:227-337.

54. Mirakabad FST, Akbarzadeh A, Zarghami N, Zeighamian V, Rahimzadeh A, Alimohammadi S: PLGA-Cased nanoparticles as cancer drug delivery systems. APJCP Asian Pac J Cancer Prev 2014, 15(1):517-535.

doi:10.1186/1475-2867-14-66

Cite this article as: Nejati-Koshki et al:: Curcumin inhibits leptin gene expression and secretion in breast cancer cells by estrogen receptors. Cancer Cell International 2014 14:66.

\section{Submit your next manuscript to BioMed Central and take full advantage of:}

- Convenient online submission

- Thorough peer review

- No space constraints or color figure charges

- Immediate publication on acceptance

- Inclusion in PubMed, CAS, Scopus and Google Scholar

- Research which is freely available for redistribution 